\title{
Trends in market reactions: stock dividends and rights offerings at Istanbul stock exchange
}

\section{Gülnur Muradoğlu \& Kürsat Aydoğan}

To cite this article: Gülnur Muradoğlu \& Kürsat Aydoğan (2003) Trends in market reactions: stock dividends and rights offerings at Istanbul stock exchange, The European Journal of Finance, 9:1, 41-60, DOI: 10.1080/13518470110047611

To link to this article: https://doi.org/10.1080/13518470110047611

曲 Published online: 19 Mar 2012.

Submit your article to this journal

山 Article views: 79

Citing articles: 7 View citing articles 


\section{Trends in market reactions: stock dividends and rights offerings at Istanbul stock exchange}

\section{GÜLNUR MURADOḠLU* and KÜRSAT AYDOG̃AN}

Manchester School of Accounting and Finance, Crawford House, Booth Street East, Manchester, M13 9PL, UK. Tel:+44 161275 3936, Fax: +44 1612754023 , E-mail: Gulnur.Muradoglu@man.ac.uk.

This paper examines the existence of different price reactions to the implementation of stock dividends and rights offerings as the stock market matures over time and the investor mix changes. For that purpose market reactions at the Istanbul Stock Exchange (ISE) are investigated during three sub-periods displaying different developmental phases of the market defined in terms of Institutional framework, transactlons volumes and related investor profiles. Differences in price reactlons and the accompanying trading volumes are tested as the investor mix changes and small Investors enter ISE due to the cultivating of awareness about the stock market. Other possible causes of excess returns such as prior knowledge about the stocks being traded or a preferred trading range are also tested. Considering the characteristics of thinly traded emerging markets, non-parametric tests are employed besides traditional event study methodology and results are immune to the choice of relevant test statistics. The results indicate that the changing mix of investors shift the timing of market reaction from announcement to implementatlon of stock dividends and rights offerings. Since Individual investors, who are attracted by lower relative prices, are not expected to be prompt in timing, excess returns persist over longer event windows and are accompanied by increasing trading volumes.

Keywords: stock divldends, rights offerings, event study, sign test, rank test

\section{INTRODUCTION}

This paper examines the existence of different price reactions to the implementation of stock dividends and rights offerings as the stock market matures over time and the investor mix changes. For that purpose, market reactions are investigated at the Istanbul Stock Exchange (henceforth ISE) during three sub-periods displaying different developmental phases of the market defined in terms of institutional framework, transactions volumes and related investor profiles. An interesting feature of the study is the distinct characteristic of the market in terms of the implementation of stock dividends and rights offerings. As will be described in detail in the next section, due to the institutional and legal framework, investors watch out for the total split factor. 
Although the accounting treatment is of course different, the split effect is the issue under Investigation.

The impact of splits on shareholder wealth is an interesting phenomenon in any stock market. This paper addresses the issue of market reaction to their implementation as the stock market matures and investor mix changes. Operating cash flows are not directly affected by stock dividend-stock split decisions and each shareholder retalns his/her proportlonate ownership. Moreover other clalms of security holders are unaffected by these occurrences. On the other hand, if stock splits were purely cosmetic, real effects such as persistent stock price reactions to such information would not be possible. Therefore, central to research in this area, are the tests of the empirical validity of several hypotheses explaining this phenomenon.

The signalling hypothesis (Fama et al., 1969) argues that the market realizes split information as a signal to re-evaluate expected income from substantial dividend increases. Recent papers also provide evidence for this hypothesis by reporting subsequent unanticipated increases in earnings per share and the positive correlation between price changes and the split factor (McNichols and Dravid, 1990). The substitution hypothesis (Scholes, 1972) assumes that the demand for a particular company's shares are perfectly elastic, so any increase due to stock splits will not lead to a fall in share price. This high demand elastlcity is alleged to the existence of alternative risky assets as close substitutes. Tests of the competing Prlce Pressure Hypothesis assume market inefficiency in the sense that stock splits/rights issues will have a depressing effect on share prices in the case of downward sloping demand curves. In mature markets, however, this hypothesis is rejected and markets appear to be highly liquid (Marsh, 1979; Smith, 1977). The trading range hypothesis (Woolridge and Chambers, 1983) assumes a popular trading range for stock prices and discusses that management, using its private information about company prospects, sets a split factor so that stock price is brought back to that trading range. Finally, price reactions are explained by the changing composition of stock investors as a result of the split decision. The hypothesis of changing mix of investors is based on the fact that the number of shareholders in a firm tends to increase after a split (Lamoureux and Poon, 1987); 1.e. a split will increase the demand for stock among small Investors which will in turn Increase liquidity and hence price. Still others investigate Issues such as accounting practices (Peterson et al., 1996), recurring splits (Pilotte and Manuel, 1996), long-term effects of splits (Ikenberry et al., 1996) and impact of splits on bid-ask spreads (Forjan and McCorry, 1995).

Literature on this field Ignores, with few exceptions, the learning process (Timmerman, 1993) and the possibility of a trend toward diminishing/increasing excess returns at different developmental stages of a market. One way to circumvent this problem is the analysis of stock price reactions to stock dividends and stock splits in an emerging market, as market structure and market participants change rapidly through time. Martikainen et al. (1991) detected significant time series variations while investigating the price reactions to earnings announcements in the Finnish stock market. They formed separate portfolios composed of stocks with positive and negative unexpected earnings 
respectively and analysed abnormal returns for both portfolios at two subperiods characterized by the improvement of quality and duration of interim reports. Excess returns of the second portfolio (negative unexpected earnings) were significantly lower than the first (positive unexpected earnings) throughout the research period. Still, cumulative abnormal returns of both portfolios were significantly higher during the second sub-period, and the drift upward had started 170 days before the event, in the second sub-perlod as opposed to 90 days in the first sub-period. The results were then interpreted as investors were following the contents of financial statements more carefully during the latter sub-period when the quality and quantity of interim reports increased rapidly.

Aydogan and Muradoğlu (1998) investigated the price reactions to the announcement and Implementation of rights issues and stock dividends by controlling for different developmental levels of the Turkish stock market. Data was collected by using a mail questionnaire that enquired about the date of the board meeting in which the stock dividend/rights offering decision was taken and the date and the means by which this Information was announced to the public. As expected, significant and persistent price reactions to the disclosure of board decisions during the first sub-perlod, faded away during the second sub-perlod as the market matured. Also, around the announcement dates, abnormal returns were not different for closely held and widely held companies Indicating that excess returns during the first sub-period were not due to the increased supply of shares from the closely held companies. However, although not statistically significant, excess returns in response to the actual implementation of stock dividends/rights offerings were higher with cumulative abnormal returns being negative for widely held companies and positive for closely held companies during the second sub-period. This study is motivated by the suggestive evidence that trends in market reaction to stock dividends/rights offerings implementation can be different from that of board decision announcements. For that purpose this phenomena is investigated with a larger sample size that includes all the firms traded at ISE and all of the stock dividend/rights offering implementations.

In this paper the focus is on the existence of different price reactions to the implementation of stock dividends and rights offerings at the Istanbul Stock Exchange as the market matures over time and the investor mix changes. For that purpose the research period is divided into three sub-periods displaying different developmental phases of the market defined in terms of institutional framework, transactlons volumes and related investor profiles. Next, the differences in price reactions around the implementation of the split decisions during the three sub-periods are examined. Then, it is investlgated whether excess returns around the Implementation of the split decision are due to a possible change in the investor $\mathrm{mlx}$. Accordingly, an analysis is made to determine if excess returns are accompanied by increased trading volumes, as the Investor mix changes and small investors enter ISE due to the cultivating of awareness about the stock market through time. Finally, other possible causes of excess returns such as prior knowledge about the stocks being traded or a preferred trading range are investigated. Also, considering the characteristics of 
thinly traded emerging markets (Cowan, 1992) non-parametric tests that do not require symmetry in cross-sectional excess returns (Corrado, 1989) are employed besides traditional event study methodology and results are immune to the choice of relevant test statistics.

Accordingly, the paper is organised as follows. In the next section data used in this study are presented with reference to the changes in market structure and market participants In the ISE. In Section 3 evidence is presented on stock price behaviour as well as relative volume change around the Implementation of rights offerings and stock dividends at different developmental phases of the market. Discussions and conclusions are given in Section 4.

\section{DATA DESCRIPTION AND TEST DESIGN}

Financial markets in Turkey were highly Inefficlent and strictly regulated until the beginning of 1980 when a liberalization package encouraged by the World Bank and IMF was Introduced. The financial liberalization programme included the liberalization of the foreign exchange regime, deregulation of interest rates, and establishment of financial markets including the Istanbul Stock Exchange (ISE), the only stock exchange in Turkey, which became operational in 1986. In 1986,42 stocks were listed and the annual volume of trade was $\$ 13$ million. Trade floor activitles were not limited to licensed brokers and individual Investors could execute their orders directly until the end of 1987. During the 1988-1989 period, orders were executed by the brokers who at the same time acted as dealers. This institutional framework led to uncertainties in the minds of investors as to the sequencing of customer versus dealer orders. At the same time, due to the low volume trade, dealer-brokers could engage In manipulative trading. This period can be characterized by a homogenous group of traders mainly composed of the dealer-brokers (Muradoğlu, 2000). Forelgn Investors were not permitted to hold stock portfolios at ISE until 1989, when controls on capital movements were lifted. The expansion of the volume of trade in 1990 is attributed to the foreign participants who were mainly institutional investors. During the 1990-1992 period, the number of professlonally managed funds increased considerably and market particlpants of this period were malnly composed of institutional investors. In 1993, computer aided trading procedures were introduced and this further increased volume of trade while changing the investor profile. Insider trading was monitored more closely and Individual Investors' participation increased due to fair trading. Since November 1994, all the stocks listed at ISE are traded by a computer-assisted system. Table 1 presents descriptive information about the growth of ISE during the research period that covers the years 1988-1994. Market capitalization, trading volume, and the number of companies listed in ISE are above those in Eastern European exchanges and other European exchanges such as Greece, Portugal and Finland.

One distinct characteristic of the Turkish stock market is the frequency and volume of stock dividends and rights offerings. Stock divldends are declared from retained earnings and the revaluation fund, an equity account created as a result of inflation adjustment of fixed assets. Starting from the 1980 s Turkey has 
Table 1. Main indicators of ISE

\begin{tabular}{|c|c|c|c|c|c|c|}
\hline Year & $\begin{array}{l}\text { Trading } \\
\text { volume }\end{array}$ & $\begin{array}{l}\text { Ave. daily } \\
\text { volume }\end{array}$ & $\begin{array}{l}\text { Ave. daily } \\
\text { no. of } \\
\text { small } \\
\text { orders }\end{array}$ & $\begin{array}{l}\text { Ave. daily } \\
\text { no. of } \\
\text { shares } \\
\text { traded }\end{array}$ & $\begin{array}{l}\text { Number of } \\
\text { listed } \\
\text { companies }\end{array}$ & $\begin{array}{l}\text { Number } \\
\text { of } \\
\text { brokerage } \\
\text { houses }\end{array}$ \\
\hline 1988 & 115 & 0.6 & $N / A$ & 0.1 mio & 79 & 18 \\
\hline 1989 & 773 & 3.0 & N/A & 0.9 mio & 76 & 20 \\
\hline 1990 & 5854 & 23.7 & 8500 & 6.2 mio & 110 & 48 \\
\hline 1991 & 8502 & 34.4 & 36900 & 18.3 mio & 134 & 110 \\
\hline 1992 & 8567 & 34.1 & 44300 & $41.0 \mathrm{mio}$ & 145 & 112 \\
\hline 1993 & 21771 & 88.5 & 221400 & $143.5 \mathrm{mio}$ & 160 & 112 \\
\hline 1994 & 23203 & 91.7 & 507000 & $395.6 \mathrm{mio}$ & 176 & 104 \\
\hline
\end{tabular}

Source: ISE (1996). Money values are in millions of US dollars.

experienced structurally high inflation rates fluctuating between $30 \%$ and $140 \%$ and corporations are permitted to adjust their financial statements for inflation by using a standard procedure called revaluation. Revaluation, as exercised in Turkey, requires increasing the value of plant assets by a constant ratio, usually comparable to the inflation rate, announced by the Ministry of Finance. When the value of plant assets and related depreciation expenses are adjusted for inflation, an account called 'revaluation fund' is credited and this account is listed under the equity. Corporations are permitted to transfer the revaluation fund to paid in capital by declaring stock dividends. Since corporations are limited to issue-debt up to $600 \%$ of pald In capital, under the high inflation rates experienced in Turkey most corporations convert the revaluation fund and retained earnings to paid in capital by declaring stock dividends so that they can maintain consistent debt to paid-In-capital ratios. Therefore accounting treatment of the aforementioned transaction is similar to a stock dividend, yet the split factor can be quite high.

In addition to stock dividends, many corporations Increase their paid-incapital by issuing new shares at par value (TL 1000) through rights offering. If new shares were sold above par the premlum was subject to corporate tax untll 1995. These shares are usually paid by simultaneously declared cash dividends, making them identical with a stock split. In most cases rights offerings are accompanled by stock dividends. Hence investors watch out for the total split factor, rather than stock dividends and rights offerings alone. Banks in Turkey are permitted to declare stock dividends only if they issue new shares for cash by the amount of conversion.

\subsection{Data}

In this study, the date on which the stock dividend/rights offering decision was implemented at ISE is used as the event date. The sample contains all the stocks listed at ISE during our research period 01/01/1988-31/12/1994. Since almost all of the companies had more than one stock dividend/rights offering during the period under examination, a total of 513 events of 169 companies are analysed. 
Of these, 73 events ( 40 firms) took place in 1988-89, 244 events ( 113 companies) took place in 1990-92 and 196 events (119 firms) between 1993 and 1994. Daily closing prices of the stocks and volume figures are obtained from the Capital Market Board of Turkey. Prices are adjusted for splits and dividends.

\subsection{Test design}

\subsubsection{Measurement of abnormal returns}

The abnormal return on stock $i$ on day $t, A R_{i n}$ is defined as the difference between daily return, $R_{i r}$ and the return on the market, $M_{r} A R_{i t}=R_{i t}-M_{r}$ The return on day $t$ is the percentage change in prices between two successive days: $R_{i t}=\left(P_{i t}-P_{t, t-1}\right) / P_{l, t-1}$ where $P_{t t}$ and $P_{t, t-1}$ represent adjusted closing prices on days $t$ and $t-1$. The market return is defined in a similar fashlon as the percentage change in the levels of ISE Composite Index In two successive days. If $t=0$ denotes the event day, the average abnormal return on $n$ stocks $t$ days after the stock dividend/rights offering decision, $A R_{p}$ is given as:

$$
A R_{t}=\sum_{i=1}^{n} \frac{A R_{i t}}{n}
$$

For $n$ securitles, average cumulative abnormal returns $T$ days after the event date, $A C A R_{\pi}$ is the sum of average abnormal returns over that perlod:

$$
A C A R_{T}=\sum_{t=0}^{T} A R_{t}
$$

The $t$-statistics for the average CARs are computed as

$$
t=\frac{\mathrm{ACAR}_{\mathrm{T}}}{\mathrm{s}(A C A)_{T}}
$$

where $s\left(A C A R_{T}\right)=s\left(A R_{T}\right)^{\star}(T+1)^{1 / 2}$ and $s\left(A R_{T}\right)$ Is the varlance over $T$ days.

An event window was considered that starts on day $t=-30$ and ends on $t=30$ and the t-tests summarized above are carrled out for thls event window. Although event days are distributed throughout the sample period, there may be overlaps across different securities as we are using a 60-day event window. In this case cross-correlations among abnormal returns might cause standard errors in the test statistic to be underestimated. The problem could be avoided if we had a single event date for all securitles, as the time serles average of abnormal returns would be equal to portfolio returns and hence account for the covariances (Brown and Warner, 1985). Alternatively the null hypothesis that the event has no impact can be tested by using unaggregated security by security data. In this method, the test statistic has poor finite sample properties and has little power (Campbell et al., 1997). Hence non-parametric tests that do not depend on the distributional properties of abnormal returns were employed 
to cross-check results based on parametric tests. In addition, for smaller event windows, non-parametric tests such as the rank test (Corrado, 1989) and sign test (Cowan, 1992) are particularly useful in detecting abnormal returns; parametric $t$-tests are employed for a 60-day event window. The longer event window adopted here, enables us to observe the possible existence of persistent abnormal returns after the event as well as price recovery before the event.

\subsubsection{Measurement of abnormal trading volume}

The relative volume of trade of stock $i$ on day $t, R V_{i t}$ is defined as the ratio of volume of trade for stock $i\left(V_{i}\right)$ to the market volume $(M V)$ on day $t$.

$$
R V_{i t}=V_{i d} / M V_{t}
$$

Measuring volume as a percentage of a firm's outstanding shares (Ajinka et al., 1991) was not indicative in this case for two reasons. At ISE, on average the percentage of firm equity open to the public is $26 \%$. While the listing requirement at ISE is only $15 \%$, the percentage of shares owned by the public ranges between $3 \%$ and $100 \%$. Besides, the average concentration ratio for the largest shareholder is 39\% (Önder, 1996). This ratio also ignores the level of trading in the overall market. Therefore, we used the relative volume of trade $\left(R V_{t}\right)$ as the measure for trading volume.

Relative Abnormal Volume, $R A V_{i t}$ is defined as the difference between daily relative volume, $R V_{t,}$ and the average relative volume for stock $i$ during a neutral

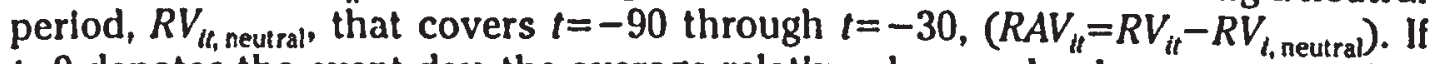
$t=0$ denotes the event day, the average relative abnormal volume on $n$ stocks $t$ days after the stock dividend-rights offering decision, $A R A V_{n}$ is given as:

$$
A R A V_{t}=\sum_{i=1}^{n} \frac{R A V_{t t}}{n}
$$

As before, an event window was considered that starts on day $t=-30$ and ends on $t=30$ and the $t$-tests summarized above are also carried out for ARAV s within this event window.

\subsubsection{Rank test}

Implementing this procedure involves first transforming each security's time serles of excess returns (volumes) into their respective ranks. $K_{i t}(t=-3, \ldots$, $+5)$ represents the rank of abnormal return (volume) $A R_{i t}\left(R A V_{i i}\right)$ in the time series of 36 daily abnormal returns (volumes) of stock $i$. The rank test procedure treats the 30-day estimation period and six-day event perlod (days zero through to five) as a single time series and assigns a rank to each daily return (volume) for each firm. By construction, rank one signifies the smallest abnormal return (volume) and rank 36 the largest; the average rank is one-half plus half the number of observed returns (volumes); 18.5 in this case. Assuming that the dally return (volume) ranks within the window are independent (Cowan, 1992), 
Corrado's rank test statistic $\left(Z_{R}\right)$ is modified as follows for the event window composed of days $D_{1}$ through $D_{d}$ :

$$
Z_{R}=\sqrt{d} \frac{\bar{K}_{d}-18.5}{\sqrt{\sum_{t=1}^{36}\left(\bar{K}_{t}-18.5\right)^{2} / 36}}
$$

$K_{d}$ is the average rank across the $n$ stocks and $d(5 \geq d \geq 1)$ days of the event window, $K_{t}$ is the average rank across $n$ stocks on day $t$ of the 36 day combined estimation and event period. Rank test statistic sample moments are close to those from a standard normal distribution for all portfolio sizes. For short return intervals and highly non-normal distributions such as dally stock returns, rank test is known to be more powerful than its parametric counterparts (Corrado, 1989).

\subsubsection{Generalized sign tests}

A generalized sign test (Cowan, 1992) examines if the number of stocks with positive cumulative abnormal returns (relative abnormal volume) exceeds the number expected in the absence of abnormal performance in the event window. The number expected is calculated as follows, by considering the fraction of positive abnormal returns (relative abnormal volume) in the 30-day estimation period;

$$
\hat{p}=\frac{1}{n} \sum_{i=1}^{n} \frac{1}{30} \sum_{t=E_{1}}^{E_{30}} S_{i t}
$$

where

$$
S_{i t}=\left\{\begin{array}{l}
1 \text { if } A R_{i t}>0 \\
0 \text { otherwise }
\end{array}\right.
$$

The generalized sign test statistic uses the normal approximation to the binomial distribution (with parameter $p$ ) and is defined as follows:

$$
Z_{G}=\frac{w-n \hat{p}}{\sqrt{n \hat{p}(1-\hat{p})}}
$$

where $w$ is the number of stocks in the event window for which the cumulative abnormal return $(C A R)$ or relative abnormal volume $\left(R A V_{i}\right)$ is positive for days

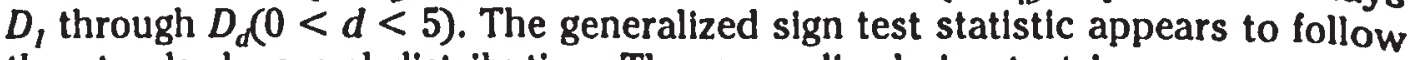
the standard normal distribution. The generalized sign test is more powerful than the rank test as the length of the event window increases and for hlghly volatile stock returns (Cowan, 1992). 


\section{FINDINGS}

For the event window that extends from $t=-30$ to $t=30$, average cumulative abnormal returns are computed first for the whole research period and then for the three sub-periods. Event day $(t=0)$ is taken as the day of the implementation of the stock dividend/rights offering decision. Table 2 summarizes the results. When the whole research period is considered, it is observed that ACARs start to pick up around $t=5$, reach $8.87 \%$ on day zero, slightly increase to $9.09 \%$ on day 10 and $9.97 \%$ on day 30 . A stronger version of the same trend is seen in the 1993-1994 sub-period. During the first sub-period 1988-1989, significant abnormal returns of $5.09 \%$ are observed on day zero only. During the second subperiod 1990-1992, significant abnormal returns up to $7.26 \%$ are observed during days zero through two. During the third sub-period 1993-1994, ACARs start to pick up around $t=-4$, reach $11.72 \%$ on day zero and continue to increase to $13.60 \%$ on day 10 , and $17.99 \%$ on day 30 . Hence, we can safely argue that the significant ACARs found for the entire research period are mainly due to the abnormal performance in the last sub-period, 1993-1994.

These results are striking in the sense that as the market matures in terms of volume and institutional framework, drifts upward begin earlier and persist longer. However, there is no economically meaningful reason for the market to respond to the implementation of stock dividend/rights offerings rather than their announcement. Therefore, it is hypothesized that market reaction is due to a possible change in the investor mix. Accordingly, an analysis is made to see if excess returns are accompanied by increased trading volumes as the investor mix changes and small investors enter ISE due to the cultivating awareness about the stock market through time. Then, other possible causes of excess

Table 2. Average cumulative abnormal returns (ACAR's) during different developmental phases of ISE

\begin{tabular}{lllll}
\hline Period & ACAR(-10) & ACAR(0) & ACAR(10) & ACAR(30) \\
\hline $1988-94$ & $1.29 \%$ & $8.87 \%$ & $9.09 \%$ & $9.97 \%$ \\
& $(1.49)$ & $(5.43)$ & $(5.08)$ & $(5.02)$ \\
$1988-89$ & $0.04 \%$ & $5.09 \%$ & $4.79 \%$ & $3.73 \%$ \\
& $(0.02)$ & $(2.13)$ & $(1.67)$ & $(1.10)$ \\
$1990-92$ & $0.75 \%$ & $7.26 \%$ & $6.37 \%$ & $4.81 \%$ \\
& $(0.64)$ & $(2.65)$ & $(2.16)$ & $(1.53)$ \\
$1993-94$ & $2.23 \%$ & 11.72 & $13.60 \%$ & $17.99 \%$ \\
& $(1.41)$ & $(4.91)$ & $(5.11)$ & $(5.79)$ \\
\hline
\end{tabular}

Note: The table presents market adjusted average cumulative abnormal returns [ACAR(t)] for all observations and three sub-samples for a 60 trading day period surrounding the implementation of stock dividends and rights offerings. The ISE composite index is used as the market index. Day zero $(t=0)$ is the day a stock dividend or a rights issue is implemented at the stock exchange. ACAR $(t)$ is calculated as described in Equation 2 in the text, with the event window starting at $t=-30$. Numbers in parentheses represent $t$ statistics calculated using Equation 3 in the text. 
returns, such as prior knowledge about the stocks being traded or the possible existence of a preferred trading range, are investigated.

In order to test whether abnormal returns during this period are due to the change in investor mix, volume figures are considered. The changing mix of investors from institutional to Individual Investors, during the third sub-period, are expected to increase trading volumes. After a split, demand among individual investors is expected to increase; this in turn will increase the number of shareholders and excess returns will be accompanled by increasing trading volumes. First, for each sub-period as well as the overall research period, the average relative abnormal volume of trade (ARAV) before and after the split are compared. While, during the first sub-perlod (1988-1989) average relative volume of trade has decreased by $15 \%$ after the split declsion, in the other two sub-periods no significant change is observed. Note here that, during the first sub period (1988-1989), significant abnormal returns due to the implementation of stock dividend/rights offerings at ISE are observed on day zero only. As Indicated in Aydoğan and Muradoḡlu (1998), during this period Information is gathered and processed by the market at the announcement rather than at the implementation of the split decision. The decrease in the average relative volume of trade after the implementation of the split decision supports this argument.

Consistent with the preceding analysls, Average Relative Abnormal Volume figures (ARAVS) are computed for the event window $t=-30$ to $t=30$, first for the whole research period and then for the three sub-perlods. The results are summarized in Table 3. An interesting feature of ARAVs is that, for all periods, except the second, abnormal volume figures are negatlve at day zero Indicating that they are lower than the average volume during the neutral period. This Interesting phenomena can be explained by two distinct properties of the market. At ISE, dally price limit is $10 \%$ in each session; price Increase or decreases cannot exceed $10 \%$ of previous sessions' average price. Intervlews with market professionals indicate that when the price of a stock hits the price ceiling after a stock split, that stock is not traded during the remainder of the trading session and this decreases the volume of trade considerably. Also, on some occasions it might take a few days for the new share to physically replace the before-split share.

It can be observed from Table 3 that no significant ARAVs are detected during the first sub-perlod, 1988-1989, except for day zero. The slgnificant decrease in volume at day zero is consistent with the $A C A R=5.09 \%$ of the same date and can clearly be explained by the $10 \%$ dally price limit at ISE. During the second subperiod, 1990-1992, ARAVs start to pick up at day $t=-11$ ( $($-value $=3.46)$, decrease considerably at $t=0$ due to the daily price celling, and increase agaln after the event. The same pattern is also observed during the third sub-period, 1993-1994. Obviously, the Increasing volume figures during the 30-day event window are consistent with the ACARs that reach a significant $17.99 \%$ during the third sub-period. This result suggests that price reactions accompanied by increased trading volumes indicate a change in the investor mix through time. As small investors enter ISE, price reactions to stock dividends and rights 
Table 3. Average relative abnormal volume (ARAV's) during different developmental phases of ISE

\begin{tabular}{lllll}
\hline Period & ARAV(-10) & ARAV(0) & ARAV(10) & ARAV(30) \\
\hline $1988-94$ & -0.21 & -0.59 & -0.36 & -0.33 \\
& $(0.68)$ & $(1.95)$ & $(1.20)$ & $(1.13)$ \\
$1988-89$ & -3.39 & -4.52 & -4.00 & -3.67 \\
& $(1.56)$ & $(2.15)$ & $(1.87)$ & $(1.73)$ \\
$1990-92$ & 0.35 & 0.07 & 0.27 & 0.16 \\
& $(2.90)$ & $(0.45)$ & $(2.43)$ & $(1.71)$ \\
$1993-94$ & 0.20 & -0.53 & 0.13 & 0.19 \\
& $(2.29)$ & $(1.33)$ & $(2.24)$ & $(1.84)$ \\
\hline
\end{tabular}

Note: The table presents the average relative abnormal volume [ARAV( $(t)]$ for all observations and three sub-samples for a 60 trading day period surrounding the implementation of stock dividends and rights offerings. Day zero $(t=0)$ is the day a stock dividend or a rights issue is implemented at the stock exchange. ARAV( $t)$ is calculated as described in Equation 5 in the text. Numbers in parentheses represent $t$ statistics calculated by adopting Equation 3 in the text.

offerings shift from the board decision (Aydoḡan and Muradoğlu, 1998) to the implementation of these decisions.

Excess returns and the accompanying increased trading volumes are observed mainly during the 1993-1994 period. It can be argued that the use of a parametric t-test in measuring abnormal performance underestimates the excess returns and abnormal volume increases during the initial phases of development, especially the 1988-1989 period when trading is thin. In order to make the results Immune to methodology non-parametric tests were employed. Non-parametric Rank Test (Corrado, 1989) and Generalized Sign Test (Cowan, 1992) statistics are computed for all groups at different time periods, for an event window of zero to five days. The estimation period is 30 days in both cases. Tables 4 and 5 report the results for days $t=0,1,3,5$. The rank test does not require symmetry in cross-sectional excess returns distributions, and therefore is more powerful in detecting abnormal returns/volumes in this case which corresponds to thin trading during the initial phases of development of the ISE. Since this relative power advantage is expected to decline with longer return intervals (Corrado, 1989), and parametric $t$-test results reveal persistent excess returns, the generalized sign $t$-test, which is relatively more powerful as the length of the event window increases (Cowan, 1992), was also employed.

It can be observed from Table 4 that for all the events between 1988 and 1994, the rank test detects abnormal returns for days zero and one $(t=0,1)$, while the sign test is more powerful in the wider event window of three days $(t=1,2,3)$. As expected, both tests are more powerful during the initial phases of the market, which is characterized by thin trading. During the 1988-89 period both tests Indicate abnormal returns for day zero $(t=0)$ only. The same phenomenon is observed for the 1990-1992 sub-period and for both groups, although the significance levels are lower. During the 1993-1994 period, excess returns are detected for days zero and one $(t=0,1)$ by the rank test and for days zero 
through to three $(t=0,1,2,3)$ by the sign test for stocks listed during the 1988-1989 period. Simllar results are found with higher significance levels and linger event windows of five days $(t=0,1,2,3,4,5)$ for stocks listed during the 1990-1992 period. For stocks listed during the 1993-1994 sub-period, mean ranks and percentage of positive excess returns are similar to those listed in earlier periods. However, significance levels vary mainly due to the different number of observations in each sub-group. Overall, nonparametric rank and generalized sign test results confirm our earlier findings that significant and persistent abnormal returns found for the entire sample is mainly due to abnormal performance during the 1993-1994 sub-period.

Table 4. Summary results of the generalized sign and rank event study test statistics for ACARs

\begin{tabular}{|c|c|c|c|c|c|}
\hline \multirow[b]{2}{*}{ Period } & \multirow[b]{2}{*}{$\begin{array}{l}\text { Event } \\
\text { window }\end{array}$} & \multicolumn{2}{|c|}{ Rank test } & \multicolumn{2}{|l|}{ Sign test } \\
\hline & & $\begin{array}{l}\text { Mean } \\
\text { rank }\end{array}$ & $\begin{array}{l}\text { Test } \\
\text { statistic }\end{array}$ & $\begin{array}{l}\text { Percentage } \\
\text { of positives }\end{array}$ & $\begin{array}{l}\text { Test } \\
\text { statistic }\end{array}$ \\
\hline 1988-1994 & $\begin{array}{l}\text { Day } 0 \\
\text { Day } 1 \\
\text { Day } 3 \\
\text { Day } 5\end{array}$ & $\begin{array}{l}22.45 \\
20.56 \\
19.11 \\
18.58\end{array}$ & $\begin{array}{l}4.32 \\
3.18 \\
1.35 \\
0.22\end{array}$ & $\begin{array}{l}63 \% \\
61 \% \\
57 \% \\
55 \%\end{array}$ & $\begin{array}{l}5.98 \\
4.92 \\
2.97 \\
1.64\end{array}$ \\
\hline \multicolumn{6}{|c|}{ (1) 1988-1989 } \\
\hline & $\begin{array}{l}\text { Day } 0 \\
\text { Day } 1 \\
\text { Day } 3 \\
\text { Day } 5\end{array}$ & $\begin{array}{l}23.53 \\
20.37 \\
18.61 \\
18.31\end{array}$ & $\begin{array}{l}3.62 \\
1.91 \\
0.16 \\
0.34\end{array}$ & $\begin{array}{l}79 \% \\
56 \% \\
53 \% \\
57 \%\end{array}$ & $\begin{array}{l}2.69 \\
1.28 \\
0.58 \\
1.29\end{array}$ \\
\hline \multicolumn{6}{|c|}{ (2) $1990-1992$} \\
\hline & $\begin{array}{l}\text { Day } 0 \\
\text { Day } 1 \\
\text { Day } 3 \\
\text { Day } 5\end{array}$ & $\begin{array}{l}22.01 \\
20.02 \\
18.82 \\
18.19\end{array}$ & $\begin{array}{r}3.13 \\
1.91 \\
0.57 \\
-0.67\end{array}$ & $\begin{array}{l}60 \% \\
56 \% \\
52 \% \\
49 \%\end{array}$ & $\begin{array}{r}3.14 \\
1.99 \\
0.58 \\
-0.45\end{array}$ \\
\hline \multicolumn{6}{|c|}{ (3) 1993-1994 } \\
\hline & $\begin{array}{l}\text { Day } 0 \\
\text { Day } 1 \\
\text { Day } 3 \\
\text { Day } 5\end{array}$ & $\begin{array}{l}22.67 \\
21.27 \\
19.67 \\
19.20\end{array}$ & $\begin{array}{l}3.98 \\
3.75 \\
2.23 \\
1.64\end{array}$ & $\begin{array}{l}66 \% \\
67 \% \\
63 \% \\
58 \%\end{array}$ & $\begin{array}{l}4.57 \\
4.86 \\
3.57 \\
2.29\end{array}$ \\
\hline
\end{tabular}

Note: The table presents the results of the rank and sign tests for ACARs for all observations and three sub-samples for a five-day $(d=1, \ldots, 5)$ event window. Day zero $(d=0)$ is the day a stock dividend or a rights issue is implemented at the stock exchange. The mean rank is the average rank of cumulative abnormal returns across the $n$ stocks and $d$ days of the event window. The rank-test statistic $\left(Z_{R}\right)$ is calculated as described in Equation 6 in the text and its sample moments are close to those from a standard normal distribution. Percentage of positives is the fraction of stocks with positive cumulative abnormal returns across the $d$ 8 and follows the standard The sign-test statistic $\left(Z_{R}\right)$ is calculated as described in Equation 
Table 5. Summary results of the generalized sign and rank event study test statistics for ARAVs

\begin{tabular}{|c|c|c|c|c|c|}
\hline \multirow[b]{2}{*}{ Period } & \multirow[b]{2}{*}{$\begin{array}{l}\text { Event } \\
\text { window }\end{array}$} & \multicolumn{2}{|c|}{ Rank test } & \multicolumn{2}{|l|}{ Sign test } \\
\hline & & $\begin{array}{l}\text { Mean } \\
\text { rank }\end{array}$ & $\begin{array}{l}\text { Test } \\
\text { statistic }\end{array}$ & $\begin{array}{l}\text { Percentage } \\
\text { of positives }\end{array}$ & $\begin{array}{l}\text { Test } \\
\text { statistic }\end{array}$ \\
\hline $1988-1994$ & $\begin{array}{l}\text { Day } 0 \\
\text { Day } 1 \\
\text { Day } 3 \\
\text { Day } 5\end{array}$ & $\begin{array}{l}12.24 \\
12.81 \\
14.06 \\
14.83\end{array}$ & $\begin{array}{l}1.25 \\
1.61 \\
1.77 \\
1.79\end{array}$ & $\begin{array}{l}30 \% \\
33 \% \\
40 \% \\
43 \%\end{array}$ & $\begin{array}{l}-8.94 \\
-7.30 \\
-4.38 \\
-3.01\end{array}$ \\
\hline (1) 1988-1989 & $\begin{array}{l}\text { Day } 0 \\
\text { Day } 1 \\
\text { Day } 3 \\
\text { Day } 5\end{array}$ & $\begin{array}{l}10.86 \\
11.96 \\
12.81 \\
13.80\end{array}$ & $\begin{array}{l}1.05 \\
1.27 \\
1.56 \\
1.57\end{array}$ & $\begin{array}{l}20 \% \\
33 \% \\
34 \% \\
41 \%\end{array}$ & $\begin{array}{r}-4.75 \\
-2.75 \\
-2.25 \\
-1.50\end{array}$ \\
\hline (2) 1990-1992 & $\begin{array}{l}\text { Day } 0 \\
\text { Day } 1 \\
\text { Day } 3 \\
\text { Day } 5\end{array}$ & $\begin{array}{l}11.36 \\
11.94 \\
13.35 \\
14.05\end{array}$ & $\begin{array}{l}1.67 \\
1.52 \\
1.69 \\
1.78\end{array}$ & $\begin{array}{l}26 \% \\
32 \% \\
35 \% \\
36 \%\end{array}$ & $\begin{array}{l}-7.17 \\
-6.25 \\
-4.54 \\
-4.27\end{array}$ \\
\hline (3) 1993-1994 & $\begin{array}{l}\text { Day } 0 \\
\text { Day } 1 \\
\text { Day } 3 \\
\text { Day } 5\end{array}$ & $\begin{array}{l}13.80 \\
14.21 \\
15.40 \\
16.16\end{array}$ & $\begin{array}{l}1.53 \\
1.99 \\
2.02 \\
1.87\end{array}$ & $\begin{array}{l}37 \% \\
38 \% \\
48 \% \\
53 \%\end{array}$ & $\begin{array}{l}-3.60 \\
-3.16 \\
-0.66 \\
-0.81\end{array}$ \\
\hline
\end{tabular}

Note: The table presents the results of the rank and sign tests for ARAVs for all observations and three sub-samples for a five-day $(d=1, \ldots, 5)$ event window. Day zero $(d=0)$ is the day a stock dividend or a rights issue is implemented at the stock exchange. The mean rank is the average rank of abnormal volumes across the $n$ stocks and $d$ days of the event window. The rank-test statistic $\left(Z_{R}\right)$ is calculated as described in Equation 6 in the text and its sample moments are close to those from a standard normal distribution. Percentage of positives is the fraction of stocks with positive abnormal volumes across the $d$ days of the event window. The sign-test statistic $\left(Z_{A}\right)$ is calculated as described in Equation 8 and follows the standard normal distribution.

Table 5 reports that for all the events between 1988 and 1994 and for all subperiods, rank test does not detect any significant $A R A V s$, while the sign test, being more powerful in the wider event window of five days $(t=0,1,2,3,4,5)$, shows that ARAVs decrease significantly. As expected, the sign test is more powerful during the initlal phases of the market that are characterized by thin trading. During the 1988-89 period the sign test indicates abnormal volume decreases for days zero through to four $(t=0,1,2,3,4)$ and the same phenomena is observed for the 1990-1992 sub-period for days zero through to five $(t=0,1,2,3,4,5)$. During the 1993-1994 period, decreases In ARAVs are detected for days zero and one $(t=0,1)$ by the sign test only. Although the rank test cannot detect any significant changes in the relative volume figures, sign test 
results also substantiate the enduring abnormal returns found during the 1993-1994 sub-period.

In order to verify our conclusions as to the reasons behind the price reactions to stock dividends and rights offerings at later stages of the development of ISE, other possible causes of excess returns such as prior knowledge about the stocks or a preferred trading range are also investigated. During the research period the number of stocks traded at ISE has increased from 40 to 169 . Investors have observed the performance of stocks listed in 1988 for eight years, but stocks listed during 1994 have been observed for only one year. Investors may be assumed to have prlor knowledge about stocks listed earlier and be uninformed about the performance of those listed during the test perlod. Since the market does react differently over time, first it is tested whether abnormal returns that begin earlier and persist longer during the 1993-1994 period are due to the prior knowledge of investors about seasoned issues. Stocks are re-grouped accordingly. Market reactions to seasoned versus newly listed stocks in terms of price and trading volume are re-evaluated in this context during each sub-period.

The 1988-1989 period contains the 40 stocks that were listed during this period and related 73 events. During the 1990-1992 period, stocks traded at ISE were divided into two groups; the first group contains the 52 stocks (121 events) that were listed at ISE during the 1988-1989 period, and the second group contains the 63 new listings (123 events) during this period. During the 1993-1994 period, stocks were grouped into three; the first group contains those listed during 1988-1989 (42 firms and 68 events), the second group contains those listed during 1990-1992 (69 firms, 116 events), and the third group contains those listed during 1993-1994 (10 firms and 12 events).

The $A C A R s$ and $A R A V s$ were computed for an event window that extends from $t=-3$ to $t=30$ for all the groups in each sub-period. As before, the event day $(t=0)$ is taken as the day of the Implementation of the stock dividends/rights offerings. The resulting ACARs and ARAVs are summarized in Tables 6 and 7 respectively. Table 6 shows that although no significant abnormal returns are detected during the first two sub-periods, during the 1993-1994 period, abnormal returns are detected for the three groups that contain stocks listed at ISE at different time periods. During the 1993-1994 investigation period, for the stocks listed during the 1988-1989 period, $A C A R$ 's start to pick up around day zero $(t=0)$ with $A C A R=8.4 \%$, and reach a significant $16.78 \%$ on day $t=30$. The same trend is observed for stocks listed during the 1990-1992 period, with ACAR's picking up on day zero with $11.71 \%$ and reaching $16.70 \%$ on day $t=30$. A stronger version of this trend is found for stocks listed during the 1993-1994 period. ACAR's start picking up earlier, reach $27 \%$ on day zero, continue to increase to $32 \%$ on day $t=10$, to $33.7 \%$ on day $t=20$ and to $40.15 \%$ on day 30 .

Results of the analysis of $A R A V$ s for seasoned versus newly issued stocks for all sub-periods are presented in Table 7. As stated previously, for both the seasoned and the newly issued stocks, significant volume decreases at day zero $(t=0)$ due to the $10 \%$ price ceiling are consistent with the significant ACARs reported at Table 3. During the first sub-period (1989-1989), ARAVs are negative throughout the event window, indicating that the relative trading volume is 
Table 6. Average cumulative abnormal returns (ACAR's) of seasoned versus newly issued stocks

\begin{tabular}{lcccc}
\hline Period & ACAR(-10) & ACAR(0) & ACAR(10) & ACAR(30) \\
\hline (1) 1988-89 & $0.04 \%$ & $5.09 \%$ & $4.79 \%$ & $3.73 \%$ \\
Listed during 1988-1989 & $(0.02)$ & $(2.13)$ & $(1.67)$ & $(1.10)$ \\
(2) 1990-1992 & & & & \\
Listed during 1988-1989 & $1.27 \%$ & 8.94 & $9.19 \%$ & $7.19 \%$ \\
& $(0.77)$ & $(1.90)$ & $(1.86)$ & $(1.38)$ \\
Listed during 1990-1992 & $0.47 \%$ & $5.80 \%$ & $4.15 \%$ & $2.2 \%$ \\
& $(0.29)$ & $(2.06)$ & $(1.29)$ & $(0.61)$ \\
(3) 1993-1994 & & & & \\
Listed during 1988-1989 & $0.11 \%$ & 8.48 & 10.41 & 16.78 \\
& $(0.04)$ & $(2.59)$ & $(2.56)$ & $(3.68)$ \\
Listed during 1990-1992 & $2.14 \%$ & $11.71 \%$ & $13.46 \%$ & 16.70 \\
& $(0.99)$ & $(3.33)$ & $(3.49)$ & $(3.81)$ \\
Listed during 1993-1994 & $11.76 \%$ & $27.40 \%$ & $32.71 \%$ & $40.15 \%$ \\
& $(1.79)$ & $(3.28)$ & $(3.25)$ & $(3.43)$ \\
\hline
\end{tabular}

Note: The table presents market adjusted average cumulative abnormal returns [ACAR(t)] for all observations and three sub-samples for a 60 trading day period surrounding the implementation of stock dividends and rights offerings. For each sub-sample, stocks are regrouped according to the calendar time they were first listed at ISE. The ISE composite index is used as the market index. Day zero $(t=0)$ is the day a stock dividend or a rights issue is implemented at the stock exchange. ACAR $(t)$ is calculated as described in Equation 2 in the text, with the event window starting at $t=-30$. Numbers in parenthesis $t$ statistics calculated using Equation 3 in the text.

lower than that during the neutral period. Note here that during this period price reactions were observed around the announcement (Aydogan and Muradoglu, 1998), but not at the implementation of the split decision as indicated by the ACARs reported in Table 3. During the second (1990-1992) and the third (1993-1994) sub-periods, although at different levels, the significant and persistent $A C A R$ s are accompanied by increasing relative trading volumes. This finding presents evidence to support the argument that the persistent price reactions (ACARs) as the market matures, are due to changing mix of investors from institutional to Individual investors. As the individual investors enter the market, after a split, demand among individual investors increases and excess returns are accompanied by increasing trading volumes.

Finally, the possible existence was examined of a popular trading range that might attract individual investors, and thus accompany the excess returns following the implementation of a stock split. For this purpose the relative price $(R V)$ which is defined by dividing the actual security price by the ISE composite Index was used, to compensate for the enormous growth of the general price level (25 times) and the ISE composite index (40 times) over the test period. While during the first sub-period (1988-1989) all the splitting stocks had prices above the ISE index value, during the second sub-period (1990-1992) 64\% and during the third sub-period (1993-1994) only $30 \%$ of them had prices above the 
ISE index value. Moreover, while ex-split prices of all securities were above the ISE index value during the first sub-period (1988-1989), during the second subperiod (1990-1992), 41\% and during the third sub-period (1993-1994) only $15 \%$ of the stocks had prices higher than the ISE index value. This indicates that the price reactions observed mainly during the later stages of development of ISE are accompanied by lower relative prices of the splitting securities.

In order to further examine the possibility of a preferred trading range, we also considered the distributional propertles of the relative prices (RVs) of the stocks before and after the implementation of the split decision. It can be observed from Table 8 that the mean and the median relative prices have declined significantly after the split during all sub-periods. The mean relative price has declined by $62 \%, 55 \%$, and $56 \%$ and the median price has declined by $46 \%, 41 \%$ and $42 \%$ respectively during the first, second and the third subperiods. It is interesting to note two distinct features of the relative prices as the market matures. First, the average pre-split relative price has declined from 10.57 to 3.82 and 1.36 during the first, second, and the third sub-periods respectively. Similarly, the median pre-split relative price has declined from 6.88 to 1.55 and 0.49 respectively. Second, as the market matures the ex-split distributions become more right-skewed and more leptocurtic. This indicates

Table 7. Average relative abnomal volume (ARAV's) of seasoned versus newly issued stocks

\begin{tabular}{lllll}
\hline Period & ARAV(-10) & ARAV(0) & ARAV(10) & ARAV(30) \\
\hline (1) 1988-89 & -3.39 & -4.52 & -4.00 & -3.67 \\
Listed during 1988-1989 & $(1.56)$ & $(2.15)$ & $(1.87)$ & $(1.73)$ \\
(2) 1990-1992 & & & & \\
Listed during 1988-1989 & 0.40 & -0.02 & 0.31 & 0.27 \\
& $(2.69)$ & $(0.67)$ & $(2.02)$ & $(1.93)$ \\
Listed during 1990-1992 & 0.21 & 0.23 & 0.15 & -0.07 \\
& $(1.15)$ & $(0.55)$ & $(1.09)$ & $(0.74)$ \\
(3) 1993-1994 & & & & \\
Listed during 1988-1989 & 0.26 & -0.14 & 0.08 & 0.02 \\
& $(1.48)$ & $(2.53)$ & $(1.03)$ & $(0.23)$ \\
Listed during 1990-1992 & 0.13 & 0.04 & 0.15 & 0.14 \\
& $(2.23)$ & $(0.69)$ & $(1.91)$ & $(2.16)$ \\
Listed during 1993-1994 & 0.19 & -0.37 & 0.26 & 2.61 \\
& $(0.85)$ & $(2.04)$ & $(0.61)$ & $(1.28)$ \\
\hline
\end{tabular}

The table presents average relative abnormal volumes [ARAV(t)] for all observations and three sub-samples for a 60 trading day period surrounding the implementation of stock dividends and rights offerings. For each sub-sample, stocks are re-grouped according to the calendar time they were first listed at ISE. The ISE composite index is used as the market index. Day zero $(t=0)$ is the day a stock dividend or a rights issue is implemented at the stock exchange. ARAV $(t)$ is calculated as described in Equation 2 in the text, with the event window starting at $t=-30$. Numbers in parentheses represent $t$ statistics calculated
according to Equation 3 in the text. 
Table 8. Distributional properties of relative price before and after split

\begin{tabular}{lrrllr}
\hline Period & Mean & SD & Median & Skewness & Kurtosis \\
\hline (1) 1988-1989 & & & & & \\
Before split & 10.57 & 10.78 & 6.88 & 1.52 & 1.62 \\
$\begin{array}{l}\text { After split } \\
\text { (2) 1990-1992 }\end{array}$ & 5.46 & 4.77 & 4.76 & 2.66 & 10.38 \\
Before split & & & & & \\
After split & 3.82 & 10.13 & 1.55 & 9.83 & 115.83 \\
(3) 1993-1994 & 1.44 & 1.44 & 0.84 & 1.75 & 3.16 \\
Before split & & & & & \\
After split & 1.36 & 3.64 & 0.49 & 6.82 & 50.20 \\
(4) 1988-1994 & 0.61 & 1.04 & 0.29 & 5.83 & 46.09 \\
Before split & & & & & \\
After split & 3.76 & 8.82 & 1.17 & 8.10 & 98.42 \\
\hline
\end{tabular}

Notes: (1) The table presents the distributional properties of relative prices before and after the split was implemented at ISE for all observations and three sub-samples. The relative price (RV) is defined by dividing the actual security price by the ISE composite index. (2) $t-$ tests indicate that for all periods mean price ratio before split is greater than that after split at $1 \%$ significance level. (3) Wilcoxon signed-rank tests indicate that the median price ratio before split is greater than that after split at $1 \%$ significance level.

that stock dividends and rights offerings are concentrated at a lower price range that might attract the small investors.

\section{CONCLUSIONS}

Relatively few attempts have been made to provide empirical evidence for the possibility of a trend towards efficiency in emerging markets where market structures, market participants and quality and availability of information change rapidly over time. In those markets overall results may lead to incorrect evaluations that a market is efficient when In fact it is not or vice versa and may create serious problems in formulating investment strategies. This study investigates the possible existence of a trend toward efficlency in ISE as the market matures and market participants change over time. For that purpose market reactions to the implementation of stock dividends and rights offerings are analysed by controlling for different developmental phases of the market.

Significant and persistent price reactlons are observed towards the end of the research perlod. Abnormal returns found for the entire research period were mainly due to the abnormal performance during the 1993-1994 period. However, there is no economically meaningful reason for the market to respond to the implementation of stock dividends and rights offerings. Therefore, the possible influence of a change in investor mix from institutional to individual investors, market participants' prior knowledge about the stocks' being traded, and a preferred trading range are the explanations being tested.

Since abnormal returns were not detected during the initial phases of development of ISE and this period is characterized by thin trading, it might be 
argued that this finding is due to the restrictlve assumptions of the traditional event study methodology. Therefore, non-parametrlc rank and generalized sign tests that are more powerful in detecting abnormal returns when the market is thin are employed. The use of non-parametric tests made our results Immune to the methodology employed. Still, earlier findings were confirmed; significant and persistent abnormal returns found for the entire research period were mainly due to the abnormal performance during the 1993-1994 sub-period.

Finally, in order to test whether abnormal returns during the 1993-1994 subperlod are due to the change in investor $\mathrm{mix}$, volume figures were considered. During the first sub-period (1988-1989), significant excess returns were not detected and the relative trading volume was lower than that during the neutral period. During the second (1990-1992) and the third (1993-1994) sub-periods, although at different levels, the significant and persistent ACARs are accompanied by trading volumes in higher than those during the neutral period outside the event window. It was also observed that the relative price after implementation of the split declines by almost 50\%, making those shares more affordable for the small investor. Hence, it can be argued that the price reactions during the later stages of development of ISE are due to the changes in investor mix from institutional to individual investors.

The contributions of the paper fall into two categorles. First, It is shown that the statistical significance of the predictability of excess returns on stocks can be converted Into economically significant results; trading strategies that outperform the market up to $40 \%$ are possible at ISE. This economic criterion for market efficiency is not based on overall results in terms of the research period concerned and the methodology employed. During the 1993-1994 period, results of both the parametric t-tests and the nonparametric sign and rank tests indicate that investing when a stock dividend/rights offering is implemented will yield excess returns in a range of $8.5 \%$ to $40 \%$ depending upon the portfolio composition and the holding period.

Second, two possible explanations are proposed to stock price reactions to split information in emerging markets. During the first two sub-perlods that were considered in this study (1988-1989 and 1990-1992) significant price reactions were not detected beyond a one-day event window. However, significant price reactions to such information are observed at ISE for a 30-day event window during the 1993-1994 perlod. Nelther operating cash flows, nor other claims of security holders are alfected with the occurrence of stock dividends and rights offerings. Then, why do we observe price reactlons and why are the price reactions confined to the 1993-1994 period?

First, similar to Martikainen et al. (1993), who report a similar pattern for the Finnish stock market in terms of earnings announcement, it is argued that price reactions in the latter sub-period can be explained by the improved quality and quantity of financial information during this period. This supply side explanation is supported by the fact that during the 1993-1994 perlod the quality and the quantity of interim reports released by Turkish firms have increased rapidly and therefore have been followed more carefully by all investors, institutional and individual alike. 
Second, simllar to Lamoureux and Poon (1987) but in a different context, it is argued that price reactions are due to the changing mix of investors. The 1988-1989 period is characterized by a homogenous group of traders mainly composed of dealer-brokers. These investors are also known to utilize insider Information to a considerable extent (Muradoğlu, 1998) and follow to stock dividends/rights offerings information from board decisions (Aydogan and Muradog̃lu, 1998). Since this homogenous group of traders utilizes stock dividend/rights offering Information at the time of board decisions, price or volume reactions are not detected at the Implementation of the split decision.

During the 1990-1992 period, market participants are mainly composed of forelgn and domestic institutional investors and split information is received mainly from announcements prior to implementation (Aydog̃an and Muradog̃lu, 1998). However, the Investor profile during the 1993-1994 period contains the individual investors as characterized by the higher number of shares traded and the small orders executed at ISE. During this perlod, besides Improved quality and quantity of Interim reports, the computer-assisted trading system and close monitoring of Insider trading increased individual investors' participation at ISE. The changing $\mathrm{mix}$ of investors from Institutional to individual investors shifted the timing of market reaction from announcement to implementation of stock dividends/rights offerings. Also, since individual investors (who are attracted by lower relative prices) are not expected to be prompt in timing, excess returns persisted over longer event windows and were accompanied by increasing trading volumes.

\section{REFERENCES}

Ajinka, B.B., Atlase, R.K. and Gift, M.J. (1991) Volume of trading and the dispersion in financlal analysts' earnings forecasts, The Accounting Review, 66, 389-401.

Aydoğan, K. and Muradoğlu, G. (1998) Do markets learn from experience? Price reaction to stock divldends in the Turkish stock market, Applied Financial Economics, 8, 41-60.

Corrado, C.J. (1989) A nonparametric test for abnormal security price performance in event studles, Journal of Financial Economics, 23, 385-95.

Cowan, A.R. (1992) Nonparametric event study tests, Review of Quantitative Finance and Accounting, 2, 343-58.

Campbell, Y.C., Lo, A.W. and MacKinlay, A.C. (1997) The Econometrics of Financial Markets, Princeton University Press.

Fama, E., Flsher, L., Jensen, M. and Roll, R. (1969) The adjustment of stock prices to new Information, International Economic Review, 10, 1-21.

Forjan, J.M. and McCorry, M.S. (1995) Evidence on the behaviors of bid-asked spreads surrounding stock split announcements, Journal of Applied Business Research, 11, 97-103.

Ikenberry, D.L., Rankine, G. and Stice, E.K. (1996) What do stock splits really signal? Journal of Financial and Quantitative Analysis, 31, 357-75.

ISE (1996) Istanbul Stock Exchange Annual Fact-book, Istanbul.

Lamoureux, C. and Poon, P. (1987) The market reaction to stock splits, The Journal of Finance, 42, 1347-1370.

Marsh, P. (1979) Equity rights Issues and the efficlency of the UK stock market, The Journal of Finance, 34, 839-863. 
Martikalnen, T. and Rothovius, T., Yli-Olli, P. (1991) On the Individual and Incremental Information content of accrual earnings, cash flows and cash dividends in the Finnish stock market, European Journal of Operational Research, 68, 318-333.

McNichols, M. and Dravid, A. (1989) Stock dlvidends, stock splits, and slgnalling, The Journal of Finance, 45, 857-879.

Muradogilu, G. (2000) Turkish Stock Market: anomalies and profit opportunitles in Security Market Imperfections in Worldwide Equity Markets, Kelm, D. and Zlemba, W. (eds). Cambridge University Press, pp. 364-389.

Muradoğlu, G. (1989) Factors Influencing Stock Demand In Turkey. Unpublished PhD Thesis, Bogazlçi University, 1989.

Ōnder, Z. (1996) Causes and consequences of ownership structure in an emerging market. Working Paper, Bilkent Unlversity Faculty of Business Administration, 1996.

Peterson, C.A., Millar, J.A. and Rimbey, J.N. (1996) The economlc consequences of accounting for stock splits, Accounting Review, 241-53.

Pilotte, E. and Manuel, T. (1996) The market's response to recurring events: the case of stock splits, Joumal of Financial Economics, 41, 111-27.

Scholes, M. (1972) The market for securitles: substitution vs. price pressure and the elfects of information share prices, Journal of Business, 45, 179-211.

Smith, C.W. (1992) Substitute methods for raising additional capltal: rights offerings versus underwritten issues, Journal of Financial Economics, December, 273-307.

TImmerman, A.G. (1993) Learning speclfication search and market efficlency with an application to the Danish market, Scandinavian Journal of Economics, 05, 157-73.

Woolridge, J.R. and Chambers, D. Reverse splits and shareholder wealth, Financial Management, 12, 5-15. 